\title{
THE POSITION OF THE VISEGRÁD COUNTRIES BY CLUSTERING METHODS BASED ON INDICATOR ENVIRONMENTAL PERFORMANCE INDEX
}

\author{
JOZEF LUKÁČ ${ }^{*}$, BOHUSLAVA MIHALČOVÁ ${ }^{1}$, EVA MANOVÁ ${ }^{1}$, ROMAN KOZEL ${ }^{2}$,
} ŠÁRKA VILAMOVA², KATARÍNA ČULKOVÁ ${ }^{3}$

\begin{abstract}
${ }^{1}$ Department of Corporate Financial Management, University of Economics in Bratislava, Faculty of Business Economics with seat in Košice, Tajovského 13, 04001 Košice, Slovak Republic; e-mail: jozef.lukac@euke.sk, bohuslava. mihalcova@euke.sk, eva.manova@euke.sk

${ }^{2}$ Department of Economics and System Control, VŠB - Technical University of Ostrava, Faculty of Mining and Geology, 17. Listopadu 15, Ostrava - Poruba, Czech Republic; e-mail: roman.kozel@vsb.cz, sarka.vilamova@vsb.cz ${ }^{3}$ Technical University of Košice, Faculty of Mining, Ecology, Process Control and Geotechnology, Letná 9, 04200 Košice, Slovak Republic; e-mail: katarina.culkova@tuke.sk
\end{abstract}

${ }^{*}$ Author for correspondence

\begin{abstract}
Lukáč J., Mihalčová, B., Manová E., Kozel R., Vilamova Š., Čulková K.: The position of the Visegrád countries by clustering methods based on indicator Environmental Performance Index. Ekológia (Bratislava), Vol. 39, No. 1, p. 16-26, 2020.

With a growing number of negative environmental burdens, several countries have increasingly begun to address the issue of environmental protection through a number of measures. Such measures include higher spending on public health, conservation of natural resources, less emission to the air, efficiency of waste sorting, reduction of water pollution, and groundwater. The contribution is based on the Environmental Performance Index (EPI) values to perform a cluster analysis of selected countries - especially OECD (organisation for Economic Co-operation and Development) countries. The database needed for analysis is the EPI indicator for the years for 2008 to 2018 . The result will be clusters that will include countries with similar results of the EPI indicators for the reference period. It will be important for us to track the position of the Slovak Republic in this analysis.
\end{abstract}

Key words: cluster analysis, environmental performance, EPI.

\section{Introduction}

The problem of preserving life on Earth is becoming a global problem. The present study is devoted to the issue of environmental pollution in the conditions of selected countries. Environmental performance is measured using the Environmental Performance Index (EPI). The EPI ranks 180 countries on 9 priority environmental issues in 2 objectives, including protection of human health and maintaining ecosystem vitality. The underlying objective of the EPI is to move the environmental debate from emotional and rhetorical arguments to 
more data- and evidence-based action that facilitates performance tracking and accountability of decision- makers (Hsu, Zomer, 2014). The Environmental Impact Assessment Directive (EIA Directive) has created a reference framework for the implementation of the system of environmental impact assessment (EIA) into the legal systems of the Member States of the European Union, including the countries belonging to the Visegrád Group (V4): Poland, Slovak Republic, the Czech Republic, and Hungary (Gałaś et al., 2015).

\section{Theoretical background}

Careful measurement of environmental trends and progress provides a foundation for effective policymaking. The 2018 EPI ranks 180 countries on 24 performance indicators across 10 issue categories covering environmental health and ecosystem vitality. These metrics provide a gauge at a national scale of how close countries are to established environmental policy goals. The EPI thus offers a scorecard that highlights leaders and laggards in environmental performance, gives insight on best practices, and provides guidance for countries that aspire to be leaders in sustainability (Yale University, 2019) (Fig. 1).

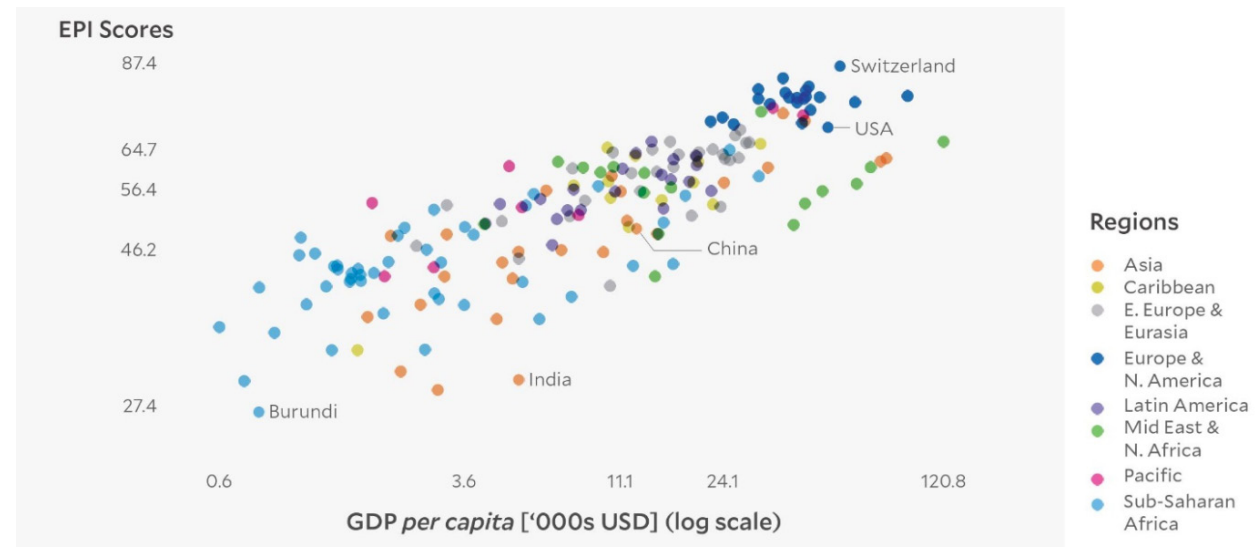

Fig. 1. Relationship between 2018 EPI Scores and GDP per capita.

France (83.95), Denmark (81.60), Malta (80.9), and Sweden (80.51) were the top 5 countries in the $2018 \mathrm{EPI}$. At the bottom of the 2018 EPI rankings are Nepal (31.44), India (30.57), the Democratic Republic of the Congo (30.41), Bangladesh (29.56), and Burundi (27.43). The Slovak Republic ranked 28th with an EPI index of 70.60. The results indicate that countries with lower EPI rating do not create money for environmental protection, air protection, water, andwaste separation. Countries with low EPI rating are often countries of the third world where the riots of civil unrest or war conflicts and most of the state budget expenditures are designed to ensure the basic course of the country. On the contrary, the country achieves a record high EPI in waste separation, expenses in public health, conservation of natural resources, and management of emissions and many other indicators (Table 1). 
T a b l e 1. Results of EPI.

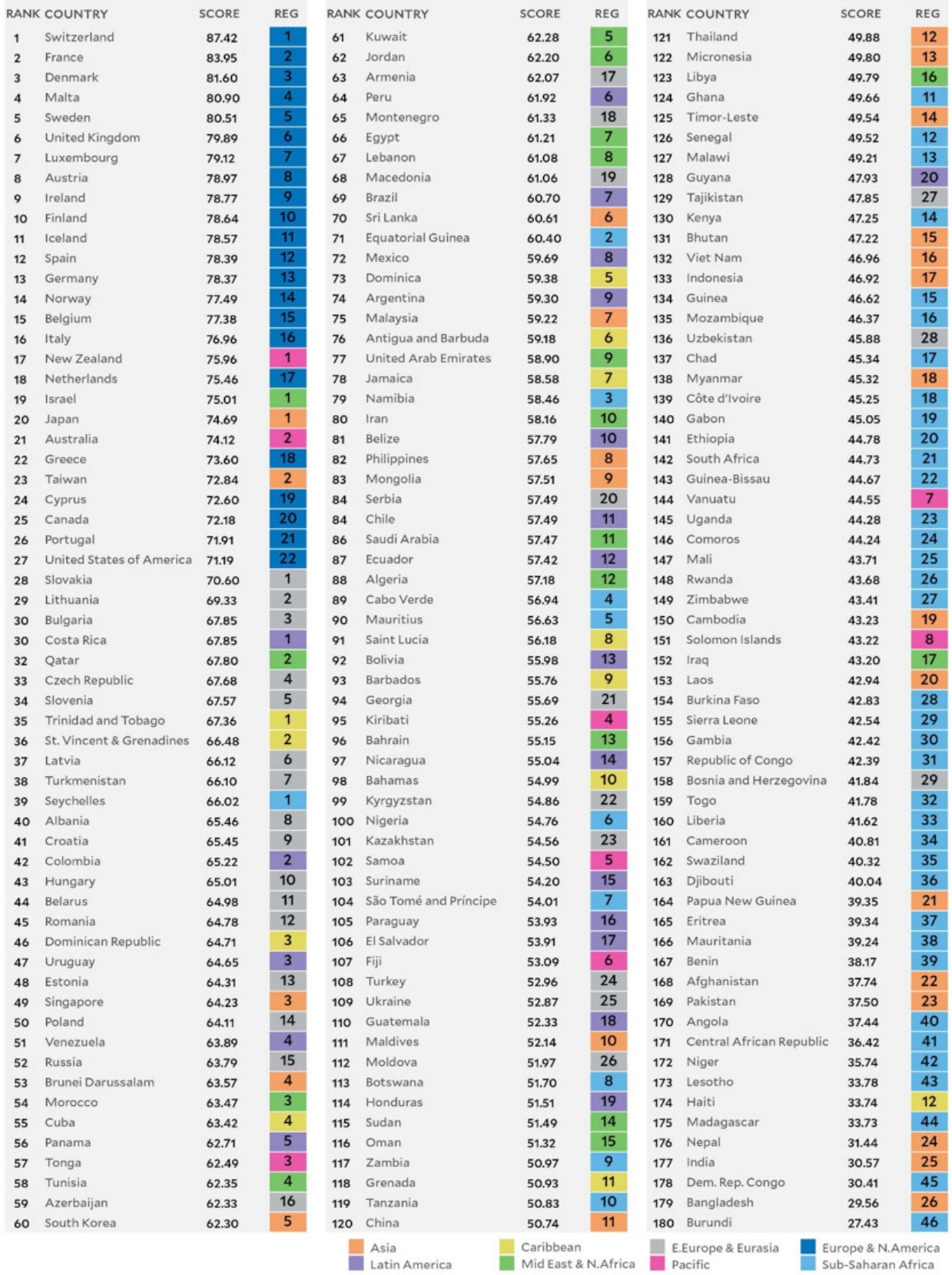


In addition to the EPI, other measurement tools are also used for measuring environmental performance. Complimen integrates parts of tools such as life cycle assessment, multi-criteria analysis, and environmental performance indicators. The popular "balanced scorecard" system can be applied in the selection and development of environmental performance indicators. As presented, the balanced scorecard integrates environmental performance within the context of corporate strategic objectives. (Johnson, 1998) EMS (Environmental management system) is a tool for managing the interaction between the organization and the environment. The aim of an EMS is to improve the overall environmental performance of the organization. The performance should be monitored through measurements, and managed by indicators. Indicators are variables that summarize or otherwise simplify relevant information about the state of a complex system. A correct evaluation of environmental performance arises from the choice of adequate "raw" data and from the relationships among "raw" data (Perotto et al., 2008).

Zhou et al. (2015) developed two slack-based efficiency measures for modeling environmental performance based on environmental DEA (Data envelopment analysis) technology. They applied the proposed measures to model the $\mathrm{CO}_{2}$ emissions in 30 OECD countries from 1998 to 2002 and presented the results obtained. Stanwick (1998) examined the relationship between the corporate social performance of an organization and three variables: the size of the organization, the financial performance of the organization, and the environmental performance of the organization. The cost-concerned school argues that environmental investments represent only increased costs, resulting in decreased earnings and lower market values. The value creation school regards environmental efforts as a way to increase competitive advantage and improve financial returns to the investors. The current research finds support for the cost-concerned school, because the results indicate that environmental performance has a negative influence on the market value of firms (Hassel et al., 2005).

According to Nakao et al. (2007), when we consider only scores of those companies that published the relevant information in their environmental reports, and conduct the statistical causality test with such information as additional input to the pooled time-series and cross-section data of financial performance, the results become more strongly significant. From the experience of environmental policies in Japan, we infer that information-based environmental policy measures are effective to encourage the ongoing transition toward a more sustainable market economy. In order to evaluate current sustainability performances of European countries from the environmental and energetic perspectives, this research proposes a multi-criteria decision analysis that, starting from both Eurostat data and the Analytic Hierarchy Process, allows a direct comparison of nations. The results show that, even nowadays, 12 of 28 European countries have a value greater than the average of values for European countries in 2013. Top four nations (Sweden, Denmark, Finland and Austria) have high indexes of sustainability and Sweden is the best country from both the environmental and energetic perspectives (Cucchiella et al., 2017).

According to Zuo (2017) the results of his research indicate that the EPI of 30 provincial administrative regions (PARs) from 2006 to 2011 ranges from 44.12 (Shanxi, 2006) to 80.87 (Beijing, 2010), from poor to good, respectively. To help develop more effective policies to improve China's regional environmental performance, cluster analysis is applied to divide 
the 30 PARs into 3 sub-regions. Recommendations for improving the environmental performance of different sub-regions are made to help guide the Chinese government to adjust environmental governance approaches to local conditions. In the article by Song et al. (2018), he first reviewed the literature on environmental performance evaluation, including evaluation theories, the methods of data envelopment analysis, and the technologies and applications of life cycle assessment and the ecological footprint. Then, he presented the theories and technologies regarding big data and the opportunities and applications for these in related areas, followed by a discussion on problems and challenges. According to the research of Haque and Ntim (2018), his evidence suggests that firms can symbolically conform to environmental policy Coca-Cola Amatil and sustainable development frameworks (GRI 307: Environmental Compliance, policy of the University of North Carolina at Greensboro) by engaging in color rendering index without necessarily improving actual environmental performance (greenhouse gas emissions) substantively.

Urbaniec (2014) identifyied the importance and relevant practices related to international standards for environmental management system in the countries of the Visegrád Group (Slovak Republic, the Czech Republic, Poland and Hungary). Papiez (2013) examined causal relationships among carbon dioxide emissions, energy consumption and economic growth using panel vector error correction modeling techniques based on the panel data for the Visegrad Group countries for the period 1992-2010. Panel co-integration tests show the existence of long-run relationships among carbon dioxide emissions, energy consumption and economic growth. The long-run equilibrium indicates that energy consumption has a positive and statistically significant impact on emissions. However, the results obtained cannot confirm the Environmental Kuznets Curve hypothesis for the Visegrád Group countries.

The environmental burden of the country in the context of tourism was analyzed by Drábova-Degro, and Krnáčová (2017). While evaluating the selected town-planning, demographical, and social economic indicators, we quantified the selective landscape preconditions of tourism development. The realization preconditions were reviewed according to communication accessibility and material technical equipment. As for environmental preconditions, we reviewed the presence of protected territory and landscape environmental load. Another analysis by Kapusta et al. (2018) dealt with the impact of environmental changes on the lakes in the Tatra Mountains. Overgrowing of shallow moraine lakes lying in the vegetation zone is a significant phenomenon of the High Tatras alpine landscape. It leads to their gradual extinction, turning into peat bogs and wet alpine meadows.

From the values emanate from the element analysis of roe deer teeth from three polluted sites (Žiar, Spiš, and Orava sites) and the control locality in the Nízke Tatry National Park, Maňkovská et al. (2012) found the highest concentrations of $\mathrm{As}, \mathrm{Cd}, \mathrm{Co}, \mathrm{Cu}, \mathrm{Hg}, \mathrm{Na}, \mathrm{Pb}$, $\mathrm{Rb}, \mathrm{Sr}$, and $\mathrm{Zn}$ in the roe deer teeth and observed a statistically significant difference in the concentration of $\mathrm{As}, \mathrm{Cd}, \mathrm{Co}, \mathrm{Cu}, \mathrm{Hg}, \mathrm{Na}, \mathrm{Pb}, \mathrm{Rb}, \mathrm{Sr}$, and $\mathrm{Zn}$ in roe deer teeth obtained from the three sites and the control locality of NAPANT. This obtained data are a useful reference point for the comparison with future measurements of air pollution in the examined area, whenever hazards due to heavy metal accumulation in the food chain are assessed.

The relationship between mining activity and landscape ecology was analyzed by Rahmonov and Szymczyk (2010). Open-mined sand exploitation always leads to the total liqui- 
dation of vegetation and soil cover. The given study presents the relations between vegetation appearing in the excavation and soil development in the initial phases of succession. Investigations were carried out in the Kuznica Warezynska sandpit located in the Silesian Upland in southern Poland. The results obtained indicate that at uncovered sands, because of exploitation in unreclaimed places, spontaneous regeneration of vegetation soil cover occurs.

\section{Methodology}

The main aim of this contribution is to identify the location of the Slovak Republic and other countries of the Vysegrád group using the clustering method. The data on which we are based represent the database of values of EPI indicators achieved for 2008, 2010, 2012, 2014, 2016 and 2018. The data obtained from this portal are first analyzed by cluster analysis using the mathematical and statistical software R-studio.

We applied the cluster analysis procedure according to Stankovičová, and Vojtková (2007). The procedure for the application of cluster analysis is given as follows:

- entering input data,

- $\quad$ selecting the type of variables,

- $\quad$ object names,

- selection of the agglomeration process,

- selection of the type of aggregation method,

- selection of the degree of similarity of objects,

- determining the number of significant clusters,

- interpretation of clusters.

For the selection of the degree of similarity of objects, we applied a distance measure called Euclidean distance, that is formulated as follows:

$$
d_{i j}=\sqrt{\sum_{k=1}^{n}\left(X_{i k}-X_{j k}\right)^{2}},
$$

where

$X_{i k}$ is the value of the $k t h$ variable for the $i t h$ enterprise, $X_{j k}$ is the value of the $k t h$ variable for the $j$ th enterprise.

This distance assumes an orthogonal coordinate system, which means mutual non-correlation of variables. The disadvantages of this type of distance include the significant influence of the absolute value (amount) of input data. This disadvantage can be eliminated by using variables in their standardized shape (form) (Stankovičová, Vojtková, 2007).

In terms of the type of aggregation (clustering) method, we have applied Ward's method (Ward's minimum variance method), which is the most used in practice. According to this method the clusters are formulated based on the maximization of homogeneity within the cluster. The homogeneity measure represents the sum of squares of deviations from the average of the cluster, called the error sum of squares (ESS) and we use the following formula for its calculation:

$$
E S S=\sum_{i=1}^{n_{h}} \sum_{h=1}^{q}\left(X_{h i}-\bar{X}_{C_{h}}\right)^{2}
$$

where

$n_{h}$ is the number of objects in the cluster $C_{h}$,

$\bar{X}_{C_{h}}$ is the vector of the average of the values of the character in the cluster $C_{h}$,

$X_{h i}$ is the vector of the values of the character of $i$ th object in the cluster $C_{h}$.

The cluster analysis is designed to create relatively homogeneous groups where it is necessary to determine an appropriate number of these groups based on various criteria, for example based on the hierarchical tree dendrogram (Stankovičová, Vojtková, 2007). 
By performing the correlation of the input variables at a significance level of $5 \%(\alpha=0.05)$, we observed the dependence (relationship) among the variables. However, the problem may be a high degree of dependence (relationship) among variables, which can affect the classification results. Deletion of the problem can be accomplished through the main components' method, in which input indicators are transformed into the new variables called as main components and they are already independent of each other. Only a few main components can reliably explain a substantial part of the overall spread of the original data. Therefore, several rules are used to determine the optimal number of components, for example,

- the number of main components should explain at least $70 \%$ of the total spread of the data,

- the number of main components determined to be used in a graphical representation of the spread is explained by main components.

\section{Research}

A prerequisite for performing cluster analysis is to examine the relationships among individual variables. The starting point for us was a correlation matrix that contains Pearson's correlation coefficients (Fig. 2).

Previously figure shows that for example in the case of the variables $\mathrm{x} 2018$, x2016 and $\mathrm{x} 2012$, all coefficients are statistically insignificant. But in case of the variable $\mathrm{x} 2014$, some of their correlations are statistically significant. This means that there may be a problem with cluster formation in cluster analysis. Therefore, it is necessary to use the main component method (to analyze the main components). We used the type of main components analysis that works with standardized variables. For the purpose of identifying the optimal number of main components (number of significant components), we calculated the shares of com-

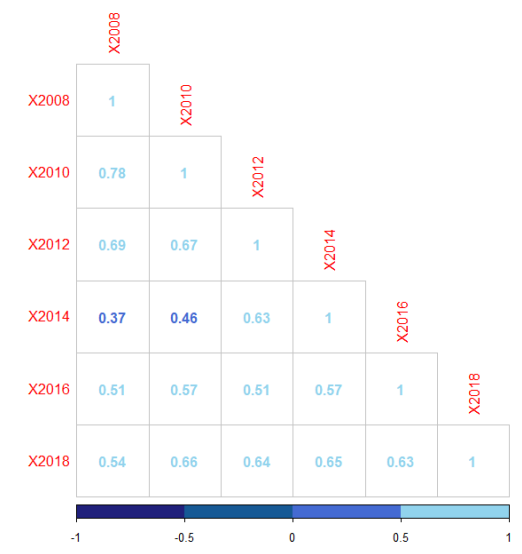

Fig. 2. Pearson correlation matrix. ponents variability in the total variability of the data from which we calculated the components (Table 2).

We can see that the first component explains the most variability and the last component explains the least variability. At the same time, we see that in order to clarify $79.189 \%$ of the variability of the original data, we need only 2 components. So we can say that we have met a rule that says the number of main components should explain at least $70 \%$ of the total spread of data. Subsequently, we also explained the variability of the original data by the components graphically using scree plot, where a graphical representation of the spread is explained by main components

T a b l e 2. Main component.

\begin{tabular}{|l|c|c|c|c|c|c|}
\hline & PC1 & PC2 & PC3 & PC4 & PC5 & PC6 \\
\hline Standard deviation & 1.994021 & 0.8804743 & 0.7068837 & 0.5785763 & 0.4822549 & 0.4261946 \\
\hline Proportion of variance & 0.662690 & 0.1292100 & 0.0832800 & 0.0557900 & 0.0387600 & 0.0302700 \\
\hline Cumulative proportion & 0.662690 & 0.7918900 & 0.8751700 & 0.9309600 & 0.9697300 & 1.000000 \\
\hline
\end{tabular}


and we found a break in the graph (Fig. 3).

On the basis of our selection, 4 main components were selected for cluster analysis, and a hierarchical tree diagram, also called as a dendrogram, was obtained (Fig. 4).

The next step was the determination of the number of significant clusters of enterprises in our analysis. On the basis

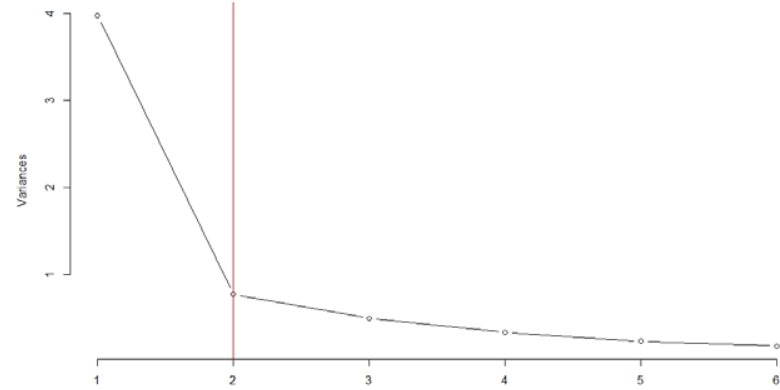

Fig. 3. Screeplot of main component. of the heuristic approach, we grouped the enterprises into 4 clusters. For this determination we also used the scree plot of number of clusters, where the number of clusters is on the $\mathrm{x}$-axis and the within cluster sum of squares is shown on the y-axis. The decisive criterion is to minimize the within cluster sum of squares, which represents the optimal situation (Fig. 5).

If we decide for more clusters, the within sum of squares would cause that the number of countries in the cluster would be too small, and conversely, a small number of clusters would cause that the within sum of squares would be too high. The number of countries in each cluster is presented (Table 3 ).

Subsequently, we have plotted the clusters in the hierarchical tree diagram, where the individual clusters are marked. Each enterprise is marked with a number (the name of country). We can see that four clusters have been created, which are mutually heterogeneous but en-

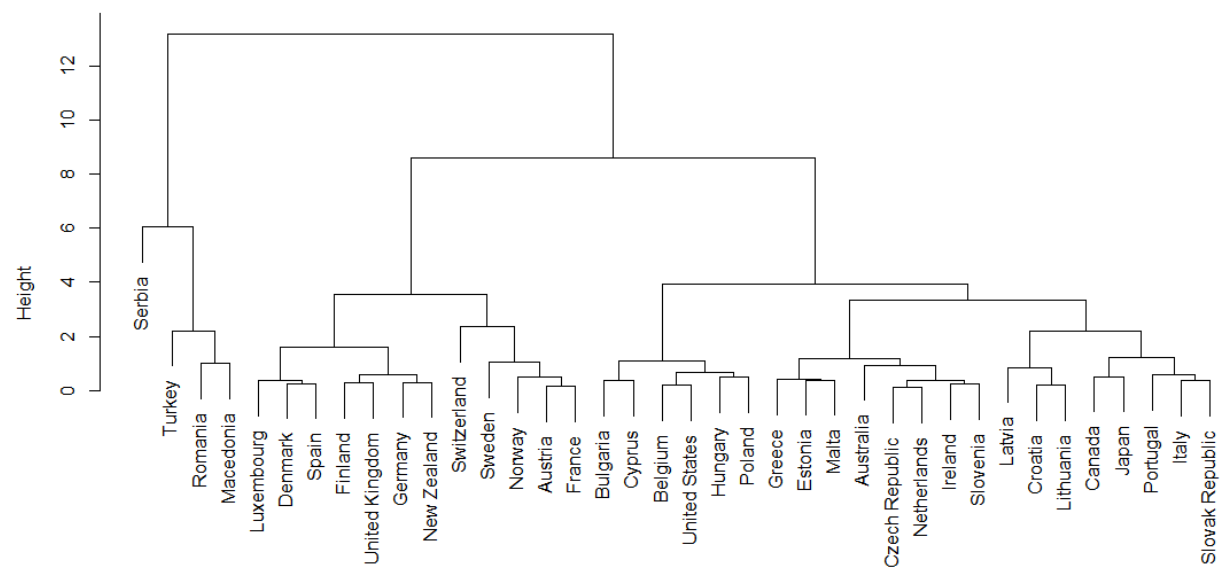

$\operatorname{dist}(\mathrm{PCA}[-1]$, method = "euclidean") hclust ( ${ }^{*}$, "ward.D2")

Fig. 4. Dendrogram. 
terprises within their cluster are homogeneous. This means that countries in one cluster have similar characteristics in terms of EPI with countries in other agglomerations (clusters) (Fig. 6).

From the results of the dendrogram itself, it is clear that the group of analyzed countries was divided into four separate clusters. The first cluster includes 12 countries, the second cluster of 22 countries, the third cluster 3 countries, and the last cluster 1 country.

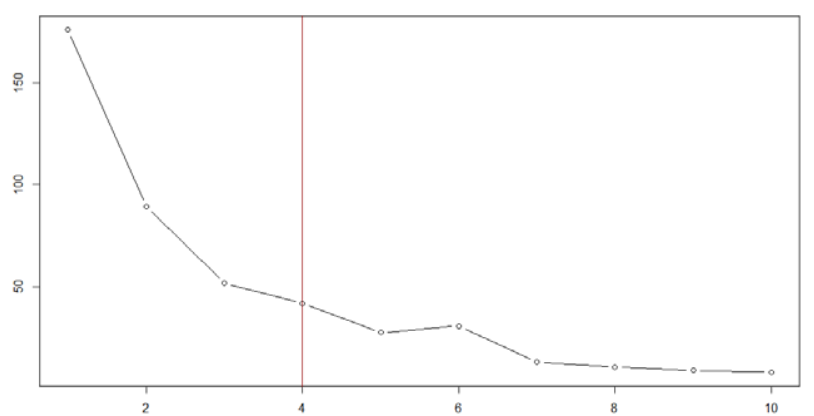

Fig. 5. Screeplot of significant cluster.

$\mathrm{T}$ a b l e 3. Screeplot of significant cluster.

\begin{tabular}{|c|c|}
\hline Cluster & Number of country \\
\hline 1. & 12 \\
\hline 2. & 22 \\
\hline 3. & 3 \\
\hline 4. & 1 \\
\hline
\end{tabular}

On the basis of the above, we can say that the Slovak Republic has ranked among the most numerous clusters together with our neighbors in the Czech Republic, Poland, Hungary, and Austria. We can also say that the countries that are in the cluster with the Slovak Republic are those that reach above average values of the EPI indicator. A cluster of 12 countries is represented by countries such as Sweden, Norway, New Zealand, and other countries that are long-term mentors in the field of reducing negative environmental impacts. Slovak Republic is in the second cluster.

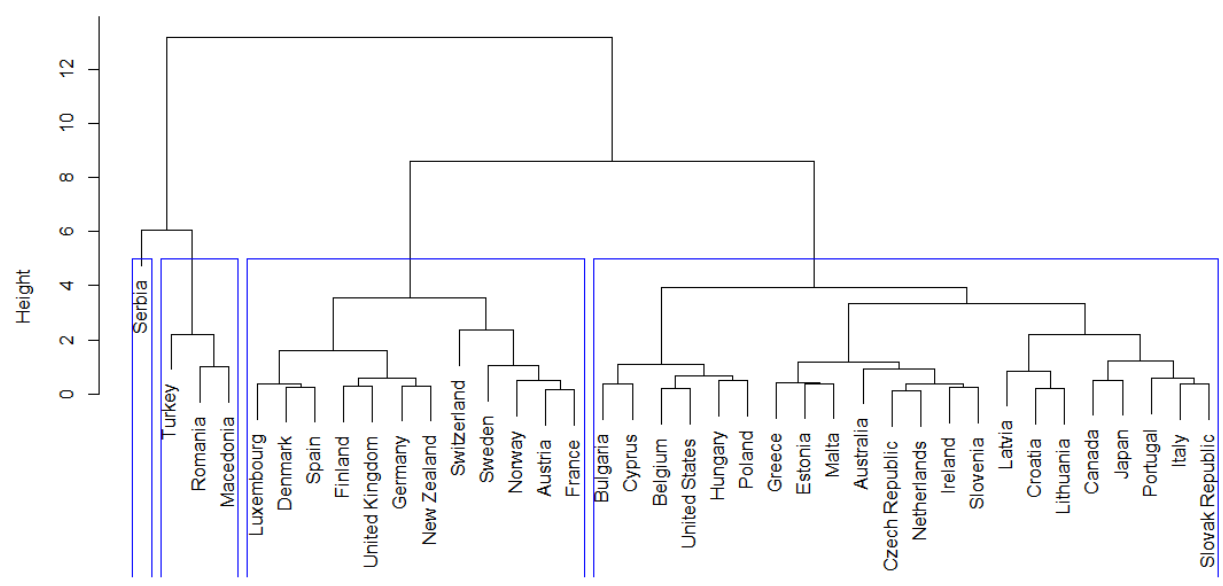

Fig. 6. Dendrogram with four clusters. 


\section{Conclusion}

The result of our analysis is the location of clustered countries based on the EPI indicator values between 2008 and 2018. On the basis of the analysis, using the Ward Method and the Euclidean Distance, we created 4 clusters containing selected OECD countries. As a result, the Republic of Slovakia joined T a b l e 4. Centroids of cluster.

\begin{tabular}{|l|l|l|l|l|l|l|}
\hline Cluster no. & $\mathbf{2 0 0 8}$ & $\mathbf{2 0 1 0}$ & $\mathbf{2 0 1 2}$ & $\mathbf{2 0 1 4}$ & $\mathbf{2 0 1 6}$ & $\mathbf{2 0 1 8}$ \\
\hline $\mathbf{1}$ & 88.50 & 76.30 & 67.72 & 78.60 & 87.84 & 80.02 \\
\hline $\mathbf{2}$ & 82.43 & 67.20 & 60.97 & 71.38 & 84.96 & 71.26 \\
\hline $\mathbf{3}$ & 74.30 & 62.67 & 46.70 & 51.93 & 76.30 & 59.60 \\
\hline $\mathbf{4}$ & 36.50 & 42.50 & 46.10 & 69.10 & 78.70 & 57.49 \\
\hline
\end{tabular}

T a b le 5. Medians of cluster.

\begin{tabular}{|l|c|c|c|c|c|c|}
\hline Cluster no. & $\mathbf{2 0 0 8}$ & $\mathbf{2 0 1 0}$ & $\mathbf{2 0 1 2}$ & $\mathbf{2 0 1 4}$ & $\mathbf{2 0 1 6}$ & $\mathbf{2 0 1 8}$ \\
\hline $\mathbf{1}$ & 88.35 & 74.45 & 68.80 & 78.05 & 87.70 & 79.05 \\
\hline $\mathbf{2}$ & 83.45 & 66.75 & 61.15 & 72.75 & 85.25 & 71.55 \\
\hline $\mathbf{3}$ & 75.10 & 60.59 & 47.00 & 50.50 & 78.00 & 61.06 \\
\hline $\mathbf{4}$ & 36.50 & 42.50 & 46.10 & 69.10 & 78.70 & 57.49 \\
\hline
\end{tabular}

the group no. 2, which includes the other countries of the Visehrád group - Poland, Hungary, the Czech Republic, and Austria. The average for centorids for each year by the EPI indicator is presented in Table 4 .

From the table, we can say that the average value of the EPI indicator varies from 2008 to 2018. For the second cluster, where the Slovak Republic is located, the average value of the indicator is 82.23 in 2008 and gradually decreases in 2010 and 2012 to 67.20 and 60.97, respectively. An increase in the indicator in 2014 and 2016 signals an improvement, but again in 2018, it drops to levels 71, and 26. We can see that even in comparison with the values for years with other clusters, cluster no. 2 is in second place (Table 5).

The previous table informs about the average values of the EPI pointer. The gap between centroid and median for clustering is that the median removes the extreme values of the EPI pointer, which may be in the clusters of the individual countries, thereby reducing the distortion of the analysis and rendering the ability of the EPI pointer. At cluster no. 2, which is also the Slovak Republic, this distortion is around \pm 1 point.

Similar results were also obtained form in the area studied, which were in the V4 countries. Vološčuk et al. (2016) presented the results acquired by an ecological analysis of vegetation succession on the field of the Slovak Karst in south-east Slovakia for the past 25 years. Fazekás et al. (2018) focused on the impacts of alkaline and metal deposition on soil and vegetation in the immission field of a magnesium factory in Jelšava-Lubeník (Slovakia).

\section{Acknowledgements}

This article is a partial output of the Project of Young Researchers and PhD Students, number I-19-110-00, 2019: Aspects of Financial Management of Towns and Municipalities in Slovakia in the Context of Financial Health.

\section{References}

Cucchiella, F., D’Adamo, I., Gastaldi, M., Koh, S.L. \& Rosa P. (2017). A comparison of environmental and energetic performance of European countries: A sustainability index. Renewable and Sustainable Energy Reviews, 78, 401-413. DOI: 10.1016/j.rser.2017.04.077. 
Drábová-Degro, M. \& Krnáčová Z. (2017). Assessment of natural and cultural landscape capacity to proposals the ecological model of tourism development (case study for the area of the Zamagurie region). Ekologia (Bratislava), 36(1), 69-87. DOI: 10.1515/eko-2017-0007.

Fazekaš, J., Fazekašová, D., Hronec, O., Benková, E. \& Boltižiar M. (2018). Contamination of soil and vegetation at a magnesite mining area in Jelšava-Lubeník (Slovakia). Ekológia (Bratislava), 37(2), 101-111. DOI: 10.2478/ eko-2018-0010.

Gałaś, S., Gałaś, A., Zeleňáková, M., Zvijáková, L., Fialová, J. \& Kubíčková H. (2015). Environmental impact assessment in the Visegrad group countries. Environmental Impact Assessment Review, 55, 11-20. DOI: 10.1016/j. eiar.2015.06.006.

Haque, F. \& Ntim C.G. (2018). Environmental policy, sustainable development, governance mechanisms and environmental performance. Business Strategy and the Environment, 27(3), 415-435. DOI: 10.1002/bse.2007.

Hassel, L., Nilsson, H. \& Nyquist S. (2005). The value relevance of environmental performance. European Accounting Review, 14(1), 41-61. DOI: 10.1080/0963818042000279722.

Hermann, B.G., Kroeze, C. \& Jawjit W. (2007). Assessing environmental performance by combining life cycle assessment, multi-criteria analysis and environmental performance indicators. Journal of Cleaner Production, 15(18), 1787-1796. DOI: 10.1016/j.jclepro.2006.04.004.

Hsu, A. \& Zomer A. (2014). Environmental performance index. Wiley StatsRef: Statistics Reference Online. DOI: 10.1002/9781118445112.stat03789.pub2.

Johnson, S.D. (1998). Identification and selection of environmental performance indicators: Application of the balanced scorecard approach. Corporate Environmental Strategy, 5(4), 34-41. DOI: 10.1016/S1066-7938(00)80079-2.

Kapusta, J., Hreško, J., Petrovič, F., Tomko-Králo, D. \& Gallik J. (2018). Water surface overgrowing of the Tatra’s lakes. Ekológia (Bratislava), 37(1), 11-23. DOI: 10.2478/eko-2018-0002.

Maňkovská, B., Oszlányi, J., Goryanova Z.I., Frontasyeva, M.V. \& Kaštier P. (2012). Regional variation in environmental element concentrations in Slovakia derived from analysis of roe deer teeth (Capreolus capreolus L.). Ekológia (Bratislava), 31(2), 138-149. DOI: 10.4149/ekol_2012_02_128.

Nakao, Y., Amano, A., Matsumura, K., Genba, K. \& Nakano M. (2007). Relationship between environmental performance and financial performance: an empirical analysis of Japanese corporations. Business Strategy and the Environment, 16(2), 106-118. DOI: 10.1002/bse.476.

Papiez, M. (2013). $\mathrm{CO}_{2}$ emissions, energy consumption and economic growth in the Visegrad Group countries: a panel data analysis. In Mathematical Methods in Economics: 3st International conference on mathematical methods in economics (pp. 696-701). Jihlava: College of Polytechnics Jihlava.

Perotto, E., Canziani, R., Marchesi, R. \& Butelli P. (2008). Environmental performance, indicators and measurement uncertainty in EMS context: a case study. Journal of Cleaner Production, 16(4), 517-530. DOI: 10.1016/j. jclepro.2007.01.004.

Rahmonov, O. \& Szymczyk A. (2010). Relations between vegetation and soil in initial succession phases in post-sand excavations. Ekológia (Bratislava), 29(4), 412-429. DOI: 10.4149/ekol_2010_04_412.

Song, M.L., Fisher, R., Wang, J.L. \& Cui L.B. (2018). Environmental performance evaluation with big data: Theories and methods. Annals of Operations Research, 270(1-2), 459-472. DOI: 10.1007/s10479-016-2158-8.

Stankovičová, I. \& Vojtková M. (2007). Viacrozmerné štatistické metódy s aplikáciami. Bratislava: Iura Edition.

Stanwick, P.A. \& Stanwick S.D. (1998). The relationship between corporate social performance, and organizational size, financial performance, and environmental performance: An empirical examination. Journal of Business Ethics, 17(2), 195-204. DOI: 10.1023/A:1005784421547.

Urbaniec, M. (2014). Implementation of international standards for environmental management in Visegrad Countries: a comparative analysis. Entrepreneurial Business and Economics Review, 2(2), 65-76. DOI: 10.15678/ EBER.2014.020206.

Vološčuk, I., Uhliarová, E., Sabo, P., Škodová, M. \& Švajda J. (2016). Succession dynamics of vegetation in the Slovak Karst Biosphere Reserve Landscape (Western Carpathians). Ekológia (Bratislava), 35(1), 13-31. DOI: 10.1515/ eko-2016-0002.

Zhou, P., Ang, B.W. \& Poh K.L. (2006). Slacks-based efficiency measures for modeling environmental performance. Ecological Economics, 60(1), 111-118. DOI: 10.1016/j.ecolecon.2005.12.001. 